\title{
Pengembangan Knowledge Management System dengan Teknik Information Retrieval
}

\author{
http://dx.doi.org/10.28932/jutisi.v7i1.3316 \\ Riwayat Artikel \\ Received: 21 Januari 2021 | Final Revision: 24 Februari 2021 | Accepted: 4 Maret 2021 \\ Try Atmaja Linggan Jaya ${ }^{\# 1}$, Mewati Ayub ${ }^{\bowtie * 2}$ \\ \# Program Studi Magister Ilmu Komputer, Universitas Kristen Maranatha \\ Jl. Surya Sumantri No.65, Bandung \\ 1atmaja94@gmail.com \\ ${ }^{2}$ mewati.ayub@it.maranatha.edu
}

\begin{abstract}
Data sets can be used as information to solve problems or share knowledge with others. In the implementation of the new system, many input errors, or obscurity of the workflow of the program, are experienced repeatedly by the same person or people in the same department. Besides that, for new employees, it takes time to adapt and solve the problem. To solve it, a system is needed to record problems and their solutions, or share knowledge, both for old and new employees as the First Aid. Knowledge Management System is expected to solve the problems as a tool to find the information needed. The knowledge consists of collected data which contains errors, causes, solutions, business flow, user authorization, and other data. The data from a collection of tickets, personal messages or e-mail, and user knowledge will be entered into the database as the storage for the knowledge. In the input process, each word will be broken down based on the character "space", tokenizing, filtering, and Vector Space Model (VSM) and stored into the database. Users can search for information by entering keywords or sentences according to user needs. The input will be processed by tokenizing, filtering, and calculating the length using VSM. After getting the input length, the results will use the TF-IDF algorithm and cosine similarity to find the information. The system will display the results in a list form and show the details if the results of the list are selected.
\end{abstract}

Keywords - Cosine Similarity; Information Retrieval; Knowledge Management System; TF-IDF; Vector Space Model.

\section{Pendahuluan}

Pengimplementasian sistem baru membuat karyawan menyesuaikan cara kerja, dan penggunaan sistem itu sendiri. Dalam pergantian sistem, hal yang pasti berubah adalah proses bisnis perusahaan dari awal proses (SO - Sales Order) hingga pembayaran pajak (setelah billing). Karena tahap penyesuaian, terdapat banyak error input data, atau error karena alur proses yang salah yang berulang - ulang setiap harinya. Karena bagian produksi bekerja selama 24 jam dan kantor bekerja 8 jam per harinya, hambatan lain yang dialami yaitu helpdesk diluar jam kerja kantor atau hari libur (Sabtu dan Minggu) sehingga menghambat kerja bagian produksi.

Maka dari itu, untuk membantu mengatasi kebutuhan user, dibutuhkan pertolongan pertama untuk user sebagai pengganti bagian helpdesk dalam pemecahan masalah yang dialami user.

Aplikasi yang akan dibangun berupa Knowledge Management System sebagai pertolongan pertama untuk mengatasi kebutuhan user. Knowledge management system adalah informasi, pengetahuan, ide, keterampilan, dan pengalaman yang diperoleh, dipertukarkan dan dibagikan diantara orang - orang, organisasi dan lembaga [3]. Pengetahuan individu dibagikan keseluruh organisasi dikarenakan pengetahuan tidak boleh hilang jika karyawan tersebut meninggalkan organisasi [3].

$K M S$ dapat didefinisikan sebagai perangkat yang dapat digunakan untuk menyimpan, menyebarkan, berkolaborasi, mengidentifikasi sumber pengetahuan untuk mendukung pembuatan, penangkapan, berbagi, pengambilan dan penggunaan pengetahuan untuk meningkatkan akses ke sumber informasi dan pengetahuan oleh individu, organisasi, dan negara secara keseluruhan [3].

Selain hal tersebut, peranan $K M S$ diharapkan dapat membantu helpdesk dalam menyelesaikan masalah baik secara flow, atau problem solving. Dengan dibuatnya suatu tempat untuk menyimpan semua informasi baik flow, error message, atau informasi lain, diharapkan dapat meringankan perusahaan dalam kebutuhan helpdesk sehingga orang yang ada dapat bekerja secara maksimal untuk kepentingan lain.

Dalam suatau organisasi KMS seperti suatu aset. Efektifitas $K M S$ bergantung pada pemanfaatan orang, proses, dan system yang ada. Pengetahuan berfokus pada pembuatan pengetahuan untuk eksplorasi dan eksploitasi pengetahuan. Pengetahuan dapat dihasilkan salah satunya 
melalui pemecahan masalah bersama yang dikumpulkan untuk dibagikan kepada banyak orang [3].

Diharapkan dengan adanya Knowledge Management System, kebutuhan user dalam mengatasi error dapat terpenuhi. Selain untuk mengatasi error, Knowledge Management System juga digunakan untuk mencatat error apa saja yang pernah terjadi, sehingga user dapat mengatasi error tersebut jika terjadi kembali di kemudian hari.

\section{TINJAUAN PUSTAKA}

\section{A. Knowledge Management System}

Pengetahuan terbagi menjadi dua bagian, yaitu pengetahuan eksplisit dan implisit. Pengetahuan eksplisit merupakan pengetahuan yang telah ada baik dalam bentuk teks, diagram, spesifikasi produk, dsb yang dapat ditemukan dalam laporan, dokumen, dan manual yang dikumpulkan dan disimpan sebagai dasar pengetahuan.

Pengetahuan implisit merupakan pengetahuan yang tidak berwujud dibandingkan dengan pengetahuan eksplisit. Pengetahuan tacit adalah dimensi dari pengetahuan implisit yang meliputi hubungan, norma, dan nilai - nilai yang tidak dapat diartikulasikan dan sulit untuk dirinci, disalin, atau didistribusikan [4].

Pengetahuan merupakan aset yang berharga untuk meningkatkan suatu organisasi atau perusahaan. Pengetahuan dibedakan menjadi 2, yaitu:

1) Tacit: Pengetahuan yang tidak mudah untuk didokumentasikan, bersifat sangat berharga atau membutuhkan penerapan yang tepat, yang didapatkan berdasarkan pengalaman dan bersifat personal.

2) Explicit: Pengetahuan yang bersifat sistematis dan dapat didokumentasikan. Berasal dari penerapan tacit dan ditulis untuk dapat dipelajari atau diterapkan oleh orang lain [5].

\section{B. Information Retrieval}

Information retrieval digunakan sebagai pencarian informasi sesuai yang dibutuhkan oleh pengguna. Berikut tahapan dalam information retrieval:

1) Tokenizing: Proses tokenizing adalah proses untuk memecah suatu kalimat menjadi kata berdasarkan suatu karakter tertentu. Proses tokenizing sangat penting peranannya karena sebagai dasar penggunaan algoritma $T F$ $I D F$ dimana dalam proses $T F$ dilakukan pengelompokan dan perhitungan kata. Karakter biasa dijadikan pemisah yaitu spasi, titik (.), koma (.), semicolon (;), dan titik dua (:) [6].

2) Filtering: Merupakan proses pembuangan kata - kata yang tidak memiliki arti. Biasanya kata - kata tersebut merupakan kata sambung dalam kalimat (dan, atau, yang). Kata yang tidak termasuk dengan kata tersebut akan dilanjutkan pada proses selanjutnya. Dari hasil tokenizing, akan dibuang kata - kata yang tidak memiliki arti atau kata penghubung [7].

3) Vector Space Model (VSM): VSM merupakan model aljabar yang digunakan untuk pengambilan informasi melalui kata - kata yang dimiliki setiap kalimat / dokumen [8]. VSM pertama kali ditemukan pada tahun 1979 oleh Salton et al. Terdapat 3 kelas pada VSM, yaitu didasarkan oleh term-document, word-context, pair-pattern matrix. VSM term-document merupakan yang paling banyak digunakan untuk mencari persamaan antar dokumen [9]. Setelah didapat nilai $T F-I D F$ tersebut, dilakukan perhitungan similarity measure dari query dengan setiap kalimat / dokumen yang ada dengan rumus.

$$
|q|=\sqrt{\sum_{j=1}^{t}\left(W_{i q}\right)^{2}}
$$

Nilai $|q|$ yang merupakan jarak query, dan $W_{i q}$ adalah bobot query dokumen ke-I, maka jarak query dihitung untuk mendapatkan jarak query dari bobot query dokumen yang terambil. Setelah mendapatkan jarak query, dilakukan perhitungan jarak dokumen dengan menggunakan

$$
\left|d_{j}\right|=\sqrt{\sum_{i=1}^{t}\left(W_{i j}\right)^{2}}
$$

Dengan didapatkannya jarak dokumen, dilakukan perhitungan similarity query dokumen (inner product) dengan menggunakan

$$
\operatorname{Sim}\left(q, d_{j}\right)=\sum_{i=1}^{t} W_{i q} \cdot W_{i j}
$$

Setelah mendapatkan bobot dari dokumen, dilakukan perhitungan cosine similarity menggunakan persamaan

$$
\operatorname{Sim}\left(q, d_{j}\right)=\frac{q \cdot d_{j}}{|q| *\left|d_{j}\right|}=\frac{\sum_{i=1}^{t} W_{i q} \cdot W_{i j}}{\sqrt{\sum_{j=1}^{t}\left(W_{i q}\right)^{2} * \sum_{i=1}^{t}\left(W_{i j}\right) 2}}
$$

Perhitungan similaritas akan menghasilkan bobot dokumen dari 0 hingga 1 atau menghasilkan bobot lebih besar dibandingkan dengan nilai yang dihasilkan dari inner product [10].

4) TF-IDF: TF-IDF merupakan algoritma untuk memeriksa relevansi kata - kata. TF-IDF berasal dari 2 kata, yaitu $T F$ (Term Frequency) untuk mengetahui berapa banyak suatu syarat muncul dalam suatu dokumen [11].

$$
T F=\text { jumlah suatu kata yang muncul }
$$

IDF (Inverse Document Frequency) pemberian bobot untuk setiap kata yang telah dihitung pada proses $T F$. Pemberian bobot dilakukan dengan cara memberi lebih rendah untuk kata-kata yang sering dan memberikan bobot lebih besar untuk kata-kata yang jarang [12].

$$
I D F=\log _{e} T F
$$

TF-IDF merupakan hasil perkalian dari TF dan IDF dengan rumus

$$
T F-I D F=T F * I D F(6)
$$

Hasil dari tokenizing dan filtering akan dikelompokan dan dihitung jumlah perkata pada proses TF dengan rumus

$$
W d t=t f d t * I D F t
$$


Keterangan:

$d \quad:$ dokumen ke- $d$

$t \quad$ : kata ke-t dari kata kunci

$W \quad:$ bobot dokumen ke- $d$ terhadap kata ke- $t$

tf : banyaknya kata yang dicari pada sebuah dokumen

$I D F \quad$ : inversed document frequency (IDF) didapatkan dari $D F: \log 2(D / d f)$

$D \quad$ : total dokumen

DF : banyak dokumen yang mengandung kata yang dicari

Setelah setiap dokumen diketahui bobotnya, dilakukan proses pengurutan dimana semakin besar nilai bobot, semakin besar tingkat kemiripan suatu dokumen terhadap kata kunci [13].

\section{Time Series ARIMA}

ARIMA yang merupakan suatu metode untuk peramalan berdasarkan data berupa deret waktu. Metode ARIMA Box Jenkins diperoleh dari $A R(p)$ dan $M A(q)$ sehingga dinamakan mernjadi $\operatorname{ARIMA}(p, q)$. Kebutuhan data time series umumnya terdapat data tidak stationer karena mean dan varians. Untuk mengatasi masalah pada mean dilakukan differencing, sedangkan untuk varians dilakukan transformasi Box-Cox. Model time series yang telah diolah tersebut dinamakan Autoregressive Integrated Moving Average (ARIMA).

Model $A R(p)$ dan $M A(q)$ dapat ditulis sebagai berikut: $Y_{t}=\varphi_{1} Y_{t-1}+\ldots+\varphi_{1} Y_{t-p}+a_{t}-\theta_{1} a_{t-1}-\ldots-a_{t-q}$

Dan model ARIMA(p,q) dapat ditulis menjadi :

Dengan

$$
\varphi_{p}(B) Y_{t}=\theta_{q}(B) a_{t} \quad(9)
$$

$$
\begin{gathered}
Y=Y_{t}-\mu(10) \\
\varphi_{p}(B)=1-\varphi_{1} B-\varphi_{2} B^{2}-\cdots-\varphi_{p} B^{p} \\
\theta_{q}(B)=1-\theta_{1} B-\theta_{2} B^{2}-\ldots-\theta_{q} B^{q}
\end{gathered}
$$

Beberapa konsep yang terdapat pada ARIMA:

1) Konsep Stationer: merupakan konsep dimana dalam proses pengolahan data yang terdapat perubahan kecenderungan dalam mean atau varians. Konsep tersebut dapat dilihat berdasarkan grafik yang sejajar dengan sumbu waktu.

2) Konsep Differencing: Konsep yang berfungsi untuk mengatasi masalah dalam pengolahan data khususnya proses yang tidak stationer dalam mean dengan mengurangi suatu pengamatan dengan pengamatan sebelumnya.

3) Konsep Transformasi Cox-Box: Konsep yang berfungsi untuk mengatasi masalah dalam pengolahan data khususnya proses yang tidak stationer dalam varians [15].

\section{Penelitian Terkait}

Literatur yang digunakan dalam penelitian ini salah satunya diambil dari penelitian Adi Ryansyah dan Sri Andayani [10] untuk implementasi information retrieval dalam mengukur kesamaan dokumen. Dalam penelitian tersebut, telah dilakukan pengukuran dengan algoritma $T F$ $I D F$ untuk pengelompokan dokumen yang sama.

Pada penelitian tersebut, terdapat suatu masalah berupa dokumen yang memiliki banyak versi sehingga dalam penggunaan dokumen tersebut tidak diketahui dokumen mana yang terbaru. Terjadinya banyak versi tersebut dikarenakan penamaan versi yang berbeda atau melakukan penyalinan dokumen.

Untuk mengurangi masalah tersebut, perlu dilakukan pengecekan tiap dokumen serta mengelompokan dokumen yang sama agar tidak terlalu banyak versi dokumen yang ada. Jika melakukan hal tersebut, tentu akan membuang waktu dalam pengecekan dokumen dengan jumlah yang banyak. Dengan menggunakan algoritma $T F-I D F$, dapat dilakukan perbandingan dokumen apakah suatu dokumen mirip dengan dokumen lain, dan juga dapat dilakukan pengelompokan dokumen jika dokumen tersebut dirasa mirip.

Dengan melakukan perhitungan kata dan pemberian bobot untuk setiap dokumen serta menghitung persamaan sudut setiap dokumen menggunakan cosine simillarity, maka akan diketahui kelompok dokumen tersebut [15].

Literatur lain yang digunakan yaitu hasil penelitian A. A. Maarif [13], dalam penelitian tersebut, algoritma TF-IDF digunakan sebagai metode pencarian informasi karya ilmiah. Kendala pencarian informasi merupakan inti dari penelitian tersebut. Bagaimana untuk mencari informasi dari data yang 8) banyak khususnya karya ilmiah. Bagi manusia tentu mudah untuk pencarian informasi yang diinginkan dengan membandingkan beberapa informasi lain, tetapi masalah akan timbul jika jumlah pembanding sangat banyak. Tentu kemampuan manusia akan terbatas dengan jumlah pembanding informasi yang sangat banyak dan akan memakan waktu yang lama dalam pencariannya.

Algoritma TF-IDF digunakan untuk pencarian informasi dari banyak data dengan membandingkan keyword yang dicari dengan judul informasi yang tersedia.

Tahap pertama yang akan dilakukan yaitu pemecahan kata berdasarkan karakter tertentu. Lalu akan dilakukan filtering dari kata - kata tersebut sebagai proses pengelompokan kata. Setelah itu dilakukan perhitungan $T F$ $I D F$ untuk mengetahui bobot setiap dokumen sebagai pembanding kemiripan [7].

Literatur lain yang dijadikan acuan adalah hasil penelitian B. Herwijayanti, D. Eka Ratnawati, dan L. Muflikhah [18], yang menggunakan algoritma TF-IDF untuk pengelompokan berita dengan studi kasus kompas.com.

Latar belakang dari penelitian tersebut dikarenakan berita yang dimasukan dapat dilakukan oleh siapa saja dan jumlahnya banyak, serta human error menyebabkan suatu berita tidak sesuai dengan kategorinya, misalkan berita yang seharusnya berkategori news dimasukan pada kategori sport.

Dengan menggunakan algoritma TF-IDF, dilakukan perbandingan judul berita yang akan dimasukan dengan judul berita yang sudah ada sehingga dapat dilakukan 
pengkategorian berita untuk meminimalisir kesalahan pengisian kategori berita [17].

Dari beberapa kajian tersebut, dapat dijadikan sebagai acuan dalam penelitian karena terdapat kemiripan tujuan penelitian yaitu perbandingan suatu kalimat dengan kalimat lain, dan pengolahan datanya berupa pencarian informasi berdasarkan suatu kata kunci. Dengan anggapan suatu informasi merupakan error message dan suatu dokumen adalah problem solving, maka dapat dilakukan perhitungan bobot untuk dilakukan pencarian informasi dalam Knowledge Management System menggunakan algoritma TF-IDF.

\section{Metodologi Penelitian}

Bagian ini menjelaskan secara rinci dan lengkap tentang metodologi / desain penelitian berdasarkan hipotesis hipotesis pada penelitian.

\section{A. Hipotesis}

Dengan dilakukan implementasi Knowledge Management System, diperkirakan beban helpdesk akan berkurang sebanyak $40 \%$, atau dapat dikatakan rata - rata tiket dengan kategori SAP yang masuk per-harinya kurang lebih sebanyak 8 tiket dalam problem solving atau pencarian informasi lain, seseorang tidak perlu menunggu respon dari departemen IT dan diperkirakan akan menemukannya dalam waktu kurang dari 3 menit.

\section{B. Analisis Penelitian}

Dalam analisis penelitian, akan dijabarkan mengenai tahapan yang dilakukan dalam penelitian daru perancangan hingga dokumentasi penelitian. Pada penelitian ini, akan dibutkan Knowledge Management System (KMS) yang digunakan oleh kurang lebih 1000 user yang terdiri dari user biasa (Non IT) dan user admin (IT) yang telah digunakan sejak bulan Juni 2020.

Dalam analisis penelitian, dilakukan rancangan penelitian terlebih dahulu untuk menentukan studi literatur, rumusan masalah, tujuan dan manfaat, penentuan metode, serta hipotesis penelitian. Setelah pembuatan rancangan, dilakukan pengumpulan data berupa pengetahuan / problem solving yang akan dibagikan pada $K M S$. Lalu dilakukan perancangan dan implementasi penelitian sesuai dengan rancangan yang dibuat dan setelahnya akan dilakukan pengecekan apakah seluruh proses sudah berjalan dengan baik atau belum, dan sudah memenuhi kebutuhan atau belum.

Dalam perancangan dan implementasi, dilakukan tahapan pembuatan KMS dimulai dari analisis kebutuhan, perancangan $U I$, perancangan database, pengumpulan dan input data. Pengumpulan data dilakukan dengan menyebarkan template untuk semua karyawan (berisikan judul / error, deskripsi / reason, dan isi pengetahuan / solving). Setelah data terkumpul, maka dilanjutkan dengan perancangan sistem (Tokenizing, Filtering, VSM, TF-IDF), pengecekan sistem sebelum digunakan, dan penerapan sistem.

Setelah semua sesuai dengan yang diharapkan, dan hasil penelitian diterapkan kepada user, akan dilakukan survei terhadap kepuasan user dalam menggunakan hasil penelitian. Hasil dari survei tersebut akan dianalisis untuk menghasilkan kesimpulan penelitian yang dapat berguna untuk hipotesis yang telah ditentukan sebelumnya dan dilakukan dokumentasi terhadap penelitian.

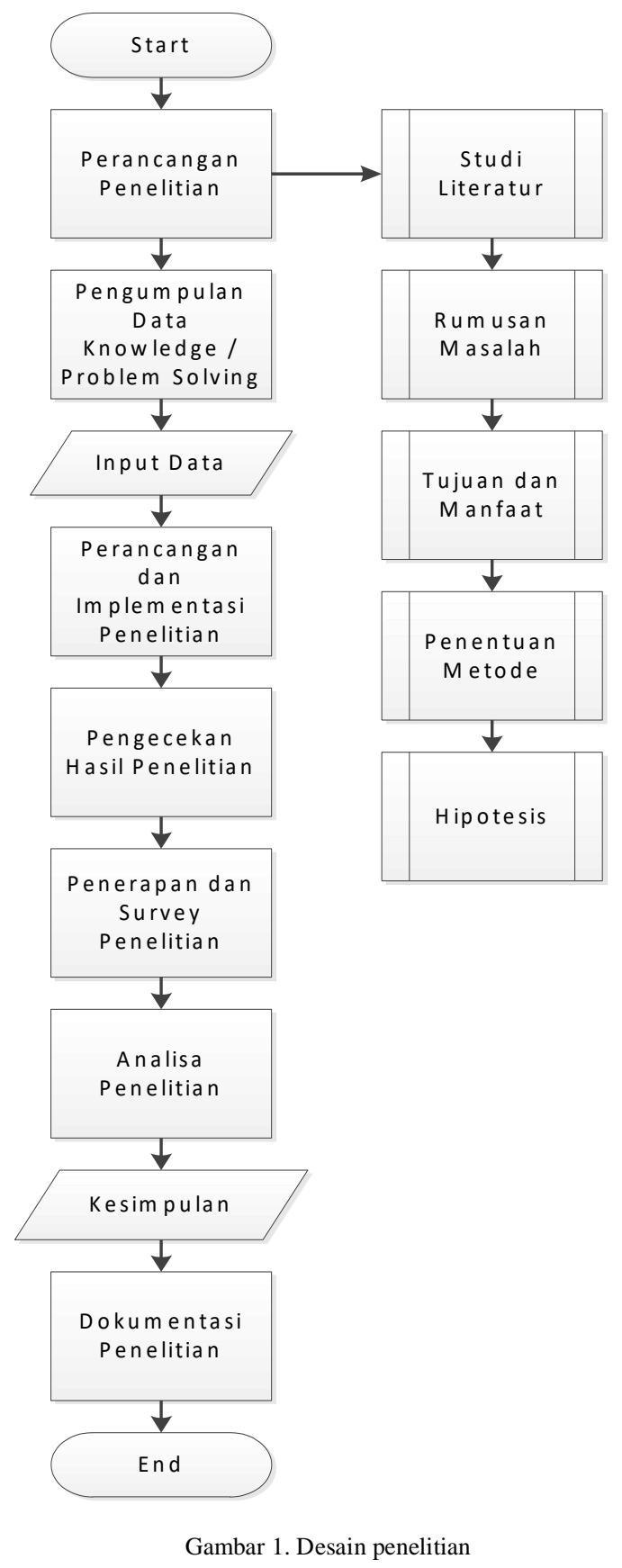

Gambar 1. Desain penelitian 
C. Perancangan dan Implementasi Penelitian

Pada perancangan dan implementasi penelitian, akan dijelaskan mengenai tahapan dalam perancangan sistem dan implementasi penelitian yang dilakukan pada sebuah perusahaan textile di Bandung.

1) VSM: Pada implementasi penelitian, VSM dilakukan pada saat kontribusi pengetahuan. Proses VSM melewati proses tokenizing, filtering, barulah VSM. Terdapat kontribusi pengetahuan berupa "Otorisasi Plan Maintenace". Maka kalimat tersebut akan dipecah berdasarkan karakter "Spasi" dan menghasilkan kata "otorisasi", "plan", dan "maintenance". Setelah itu akan dilakukan pengecekan apakah kata tersebut sudah pernah ada atau belum, jika belum maka akan ditambahkan kata kunci baru pada "tbWords" dan dihitung length-nya, dan jika sudah ada, maka akan ditambahkan jumlah nya dan dihitung length-nya.

2) Tokenizing: Terdapat 3 informasi berupa:

Kata 1: Untuk menambahkan otorisasi equipment list

Kata 2: Status Equipment DCTV

Kata 3: Otorisasi Plant Maintenance

Kata kunci yang akan dicari adalah "Otorisasi equipment list". Maka, proses tokenizing berdasarkan karakter spasi akan ditunjukkan pada tabel I.

TABEL I

HASIL TOKENIZING

\begin{tabular}{|c|c|c|c|c|c|}
\hline Keywords & otorisasi & equipment & list & otorisasi & equipment \\
\hline Kata 1 & Untuk & menambahkan & DCTV & & \\
\hline Kata 2 & Status & Equipment & Maintenance & & \\
\hline Kata 3 & Otorisasi & Plant & & \\
\hline
\end{tabular}

3) Filtering: Merupakan proses pembuangan kata - kata yang tidak memiliki arti. Biasanya kata - kata tersebut merupakan kata sambung dalam kalimat (dan, atau, yang, dsb). Kata yang tidak termasuk dengan kata tersebut akan dilanjutkan pada proses selanjutnya.

Dari hasil tokenizing, akan dibuang kata - kata yang tidak memiliki arti atau kata penghubung. Maka proses filtering seperti tabel II.

TABEL II

HASIL FILTERING

\begin{tabular}{|c|c|c|c|c|c|}
\hline Keywords & otorisasi & equipment & list & \\
\hline Kata 1 & Untuk & menambahkan & otorisasi & equipment & list \\
\hline Kata 2 & Status & Equipment & DCTV & & \\
\hline Kata 3 & Otorisasi & Plant & Maintenance & \\
\hline
\end{tabular}

Kata "Untuk" yang diberi warna merah pada Kata 1 akan dibuang, sehingga Kata 1 hanya memiliki kata "Menambahkan", "Otorisasi”, "Equipment", "List" saja.

4) TF-IDF: Berikut merupakan proses pengolahan data dengan menggunakan algoritma TF-IDF dimana pada tabel III akan dilakukan perhitungan jumlah kata dari setiap kata yang muncul $(T F)$. Sebelum melakukan perhitungan jumlah kata, dilakukan proses persamaan format kata (Uppercase atau Lowercase).

TABEL III

PROSES PERHITUNGAN KATA

\begin{tabular}{|c|c|c|c|c|c|c|c|c|}
\hline & otorisasi & equipment & list & menambahkan & status & dctv & plant & maintenance \\
\hline Kata 1 & 1 & 1 & 1 & 1 & 0 & 0 & 0 \\
\hline Kata 2 & 0 & 1 & 0 & 0 & 1 & 1 & 0 \\
\hline Kata 3 & 1 & 0 & 0 & 0 & 0 & 0 & 1 \\
\hline
\end{tabular}


Pada tabel IV dilakukan perhitungan IDF menggunakan rumus (5), dan didapatkan hasil seperti berikut.

TABEL IV

PROSES PERHITUNGAN IDF

\begin{tabular}{|c|c|c|c|}
\hline otorisasi & 2 & $\log 2 \frac{3}{2}$ & 0.585 \\
\hline equipment & 2 & $\log 2 \frac{3}{2}$ & 0.585 \\
\hline list & 1 & $\log 2 \frac{3}{1}$ & 1.585 \\
\hline menambahkan & 1 & $\log 2 \frac{3}{1}$ & 1.585 \\
\hline status & 1 & $\log 2 \frac{3}{1}$ & 1.585 \\
\hline detv & 1 & $\log 2 \frac{3}{1}$ & 1.585 \\
\hline plant & 1 & $\log 2 \frac{3}{1}$ & 1.585 \\
\hline maintenance & 1 & $\log 2 \frac{3}{1}$ & 1.585 \\
\hline
\end{tabular}

Pada tabel V dilakukan perhitungan menggunakan rumus TF-IDF (6), maka didapatkan hasil seperti berikut.

TABEL V

PROSES PERHITUNGAN TF-IDF

\begin{tabular}{|c|c|c|c|c|c|c|c|c|}
\hline & otorisasi & equipment & list & menambahkan & status & dctv & plant & maintenance \\
\hline Kata 1 & 0.585 & 0.585 & 1.585 & 1.585 & 0 & 0 & 0 & 0 \\
\hline Kata 2 & 0 & 0.585 & 0 & 0 & 1.585 & 1.585 & 0 & 0 \\
\hline Kata 3 & 0.585 & 0 & 0 & 0 & 0 & 0 & 1.585 & 1.585 \\
\hline
\end{tabular}

Pada tabel VI dilakukan perhitungan weight keyword $d$ dengan menggunakan rumus (7).

TABEL VI

PROSES PERHITUNGAN TF-IDF UNTUK KEYWORD

\begin{tabular}{|l|c|c|c|c|c|c|c|c|}
\hline & otorisasi & equipment & list & menambahkan & status & dctv & plant & maintenance \\
\hline Keyword & 0.145 & 0.145 & 0.396 & 0 & 0 & 0 & 0 & 0 \\
\hline
\end{tabular}

Pada tabel VII dilakukan perhitungan Length setiap kalimat menggunakan VSM dengan rumus (2).

TABEL VII

PROSES PERHITUNGAN LENGTH UNTUK SETIAP KALIMAT

\begin{tabular}{|c|c|}
\hline Length Kata 1 & 2.389 \\
\hline Length Kata 2 & 2.317 \\
\hline Length Kata 3 & 2.317 \\
\hline Length Keyword & 0.447 \\
\hline
\end{tabular}

Pada tabel VIII dilakukan perhitungan CosSin Similarity dengan menggunakan rumus (4).
TABEL VIII

PROSES PERHITUNGAN LENGTH UNTUK SETIAP KALIMAT

\begin{tabular}{|l|l|}
\hline \multicolumn{2}{|c|}{ Similarity } \\
\hline Cosine Kata 1 & 0.748 \\
\hline Cosine Kata 2 & 0.083 \\
\hline Cosine Kata 3 & 0.083 \\
\hline
\end{tabular}

Dari perhitungan tabel I hingga tabel VIII, maka didapatkan bahwa kata yang mendekati dengan keyword "otorisasi equipment list" adalah Kata 1 "untuk menambahkan otorisasi equipment list" dan algoritma TF$I D F$ dapat digunakan untuk pencarian informasi atau error message.

5) Pengembangan Sistem: Dalam pembuatan sistem, dilakukan beberapa tahapan hingga sistem digunakan oleh 
user. Setelah implementasi sistem, dilakukan pengembangan terus menerus yang disesuaikan dengan kebutuhan sistem dan user. Berikut merupakan tahapan dan pengembangan yang telah dilakukan yang dapat dilihat pada tabel IX.

TABEL IX

PROSES PERHITUNGAN LENGTH UNTUK SETIAP KALIMAT

\begin{tabular}{|c|c|c|}
\hline Bulan & Pengembangan & Keterangan \\
\hline April 2020 & $\begin{array}{l}\text { Analisis Kebutuhan } \\
\text { User }\end{array}$ & $\begin{array}{l}\text { Untuk mengetahui } \\
\text { kebutuhan } \text { user } \\
\text { terhadap solusi yang } \\
\text { akan ditawarkan. }\end{array}$ \\
\hline April 2020 & Perancangan Sistem & $\begin{array}{l}\text { Dilakukan rancangan } \\
\text { sistem sebagai analisis } \\
\text { sebelum pembuatan } \\
\text { sistem yang disesuaikan } \\
\text { dengan kebutuhan user. }\end{array}$ \\
\hline Mei 2020 & Pembuatan database & $\begin{array}{l}\text { Pembuatan database } \\
\text { sesuai dengan analisis } \\
\text { sebelumnya dan } \\
\text { kebutuhan sistem }\end{array}$ \\
\hline Mei 2020 & Implementasi Sistem & $\begin{array}{l}\text { Pembuatan sistem } \\
\text { sesuai dengan } \\
\text { perancangan yang telah } \\
\text { dibuat. }\end{array}$ \\
\hline Juni 2020 & Uji coba sistem & $\begin{array}{l}\text { Dilakukan uji coba } \\
\text { sistem yang telah } \\
\text { dibuat, apakah sudah } \\
\text { sesuai atau belum. }\end{array}$ \\
\hline Juni 2020 & Pengecekan Sistem & $\begin{array}{l}\text { Dilakukan pengecekan } \\
\text { sistem sebelum } \\
\text { digunakan oleh } \text { user. }\end{array}$ \\
\hline Juli 2020 & $\begin{array}{l}\text { Implementasi Sistem } \\
\text { (Go Live) }\end{array}$ & $\begin{array}{l}\text { Dilakukan } \\
\text { implementasi sistem } \\
\text { kepada user. }\end{array}$ \\
\hline $\begin{array}{l}\text { Oktober } \\
2020\end{array}$ & $\begin{array}{l}\text { Perubahan code PHP } \\
\text { native menjadi PDO }\end{array}$ & $\begin{array}{l}\text { Agar code lebih rapih } \\
\text { dan mudah untuk } \\
\text { digunakan. }\end{array}$ \\
\hline $\begin{array}{l}\text { November } \\
2020\end{array}$ & $\begin{array}{l}\text { Penambahan table } \\
\text { tbLogSearch pada } \\
\text { database }\end{array}$ & $\begin{array}{l}\text { Untuk menyimpan } \\
\text { historical pencarian } \\
\text { user. }\end{array}$ \\
\hline $\begin{array}{l}\text { Desember } \\
2020\end{array}$ & $\begin{array}{l}\text { Penambahan table } \\
\text { tbWords pada } \\
\text { database }\end{array}$ & $\begin{array}{l}\text { Untuk menyimpan hasil } \\
\text { perhitungan VSM pada } \\
\text { saat input. }\end{array}$ \\
\hline $\begin{array}{l}\text { Desember } \\
2020\end{array}$ & $\begin{array}{l}\text { Perubahan code } \\
\text { Contribution dan } \\
\text { Search Knowledge }\end{array}$ & $\begin{array}{l}\text { Perubahan code dimana } \\
\text { proses tokenizing, } \\
\text { filtering, TF dan } \\
\text { perhitungan length data } \\
\text { yang sudah ada } \\
\text { dilakukan pada proses } \\
\text { input sebagai penerapan } \\
\text { VSM dan akan } \\
\text { dimasukan kedalam } \\
\text { tbWords. untuk proses } \\
\text { search knowledge } \\
\text { dilakukan proses } \\
\text { tokenizing, filtering, TF } \\
\text { dan perhitungan length } \\
\text { untuk input-an saja } \\
\text { yang akan digabungkan } \\
\text { dengan data dari table } \\
\end{array}$ \\
\hline
\end{tabular}

\begin{tabular}{|l|l|l|}
\hline Bulan & Pengembangan & \multicolumn{1}{c|}{ Keterangan } \\
\hline & & tbWords. \\
\hline
\end{tabular}

\section{IV.PERANCANGAN DAN IMPLEMENTASI}

Dalam perancangan dan implementasi penelitian, akan dibahas mengenai tahapan - tahapan yang dilakukan dalam aplikasi yang dibuat dari proses tokenizing hingga pemberian kandidat solusi. Dalam proses temu balik informasi, tidak dilakukan proses index secara berkala saat ada penambahan pengetahuan dan dilakukan pada saat pencarian solusi, dikarenakan data yang dijadikan acuan pencarian cenderung pendek, sehingga dirasa tidak diperlukan untuk proses index tersebut. Oleh karena itu, pada perancangan penelitian, TF-IDF digunakan untuk proses index setiap kata yang akan menghasilkan kata, jumlah kata, dan length setiap kata pada proses kontribusi, dan VSM digunakan untuk menentukan similarity untuk setiap kalimat pada proses pencarian yang akan mengambil data hasil TF-IDF per kata, dan menghitung cosine similarity untuk menentukan solusi yang akan ditampilkan

\section{A. Entity Relationship Diagram (ERD)}

Gambar 2 merupakan rancangan database yang akan digunakan. Terdapat 8 table yang berisikan 3 table utama pada sistem KMS dan 5 table tambahan yang diambil dari sistem lain. 3 table utama tersebut yaitu "tbLogSearch" yang berisikan riwayat pencarian user, "tbKnowledge" yang berisikan kumpulan informasi / pengetahuan, dan "tbWords" yang berisikan kata yang telah dipecah, dan dihitung jumlah serta length-nya yang digunakan sebagai konsep dari VSM. 


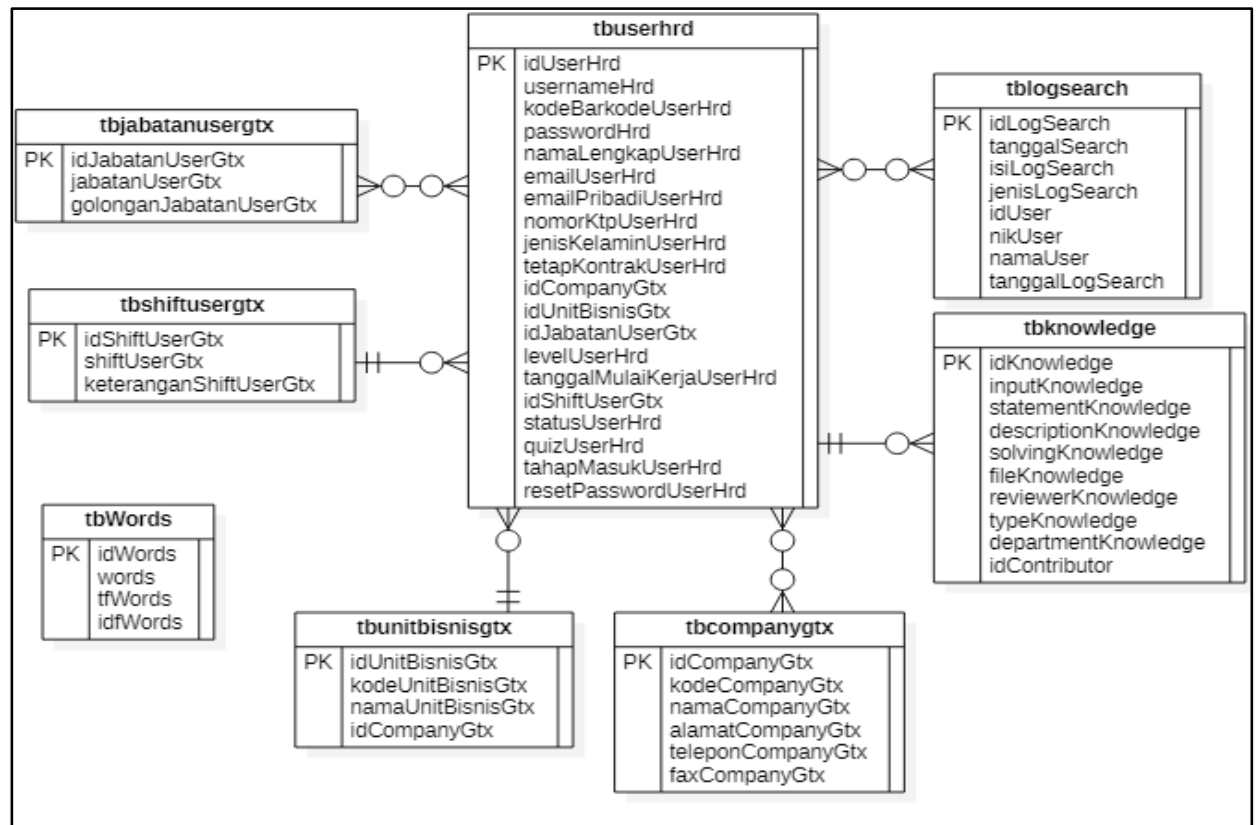

Gambar 2. Entity Relationship Diagram (ERD)

Tabel X merupakan penjelasan detail mengenai tabel yang dipakai untuk kebutuhan KMS.

TABEL $X$

TABEL KETERANGAN DETAIL ERD

\begin{tabular}{|c|c|c|}
\hline Tabel & $\begin{array}{c}\text { Deskripsi / } \\
\text { Struktur }\end{array}$ & Tujuan \\
\hline tbUserHrd & $\begin{array}{l}\text { Merupakan tabel } \\
\text { yang berisikan } \\
\text { informasi } u s e r\end{array}$ & $\begin{array}{l}\text { Digunakan } \\
\text { untuk login dan } \\
\text { melihat } \\
\text { informasi user }\end{array}$ \\
\hline tbCompanyGtx & $\begin{array}{l}\text { Merupakan tabel } \\
\text { yang berisikan } \\
\text { daftar perusahaan }\end{array}$ & $\begin{array}{l}\text { Digunakan } \\
\text { sebagai foreign } \\
\text { key pada tabel } \\
\text { tbUserHrd untuk } \\
\text { menunjukan } \\
\text { user tersebut } \\
\text { berada pada } \\
\text { perusahaan apa }\end{array}$ \\
\hline tbUnitBisnisGtx & $\begin{array}{l}\text { Merupakan tabel } \\
\text { yang berisikan } \\
\text { daftar departemen }\end{array}$ & $\begin{array}{l}\text { Digunakan } \\
\text { sebagai foreign } \\
\text { key pada tabel } \\
\text { tbUserHrd untuk } \\
\text { menunjukan } \\
\text { user tersebut } \\
\text { berada pada } \\
\text { departemen apa }\end{array}$ \\
\hline tbJabatanUserGtx & $\begin{array}{l}\text { Merupakan tabel } \\
\text { yang berisikan } \\
\text { daftar jabatan }\end{array}$ & $\begin{array}{l}\text { Digunakan } \\
\text { sebagai foreign } \\
\text { key pada tabel } \\
\text { tbUserHrd } \\
\text { untuk } \\
\text { menunjukan } \\
\text { user tersebut } \\
\text { memiliki }\end{array}$ \\
\hline
\end{tabular}

\begin{tabular}{|c|c|c|}
\hline Tabel & $\begin{array}{l}\text { Deskripsi / } \\
\text { Struktur }\end{array}$ & Tujuan \\
\hline & & jabatan apa \\
\hline tbShiftUserGtx & $\begin{array}{l}\text { Merupakan tabel } \\
\text { yang berisikan } \\
\text { daftar shift }\end{array}$ & $\begin{array}{l}\text { Digunakan } \\
\text { sebagai foreign } \\
\text { key pada tabel } \\
\text { tbUserHrd untuk } \\
\text { menunjukan } \\
\text { user tersebut } \\
\text { berada pada shift } \\
\text { apa }\end{array}$ \\
\hline tbLogSearch & $\begin{array}{l}\text { Merupakan tabel } \\
\text { yang berisikan } \\
\text { historical } \\
\text { pencarian } \text { user } \\
\text { pengguna } K M S\end{array}$ & $\begin{array}{l}\text { Digunakan } \\
\text { sebagai analisis } \\
\text { pencarian } \text { user }\end{array}$ \\
\hline
\end{tabular}

\section{B. System Relation}

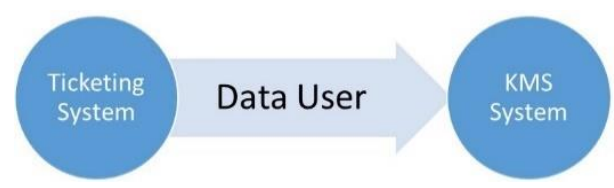

Gambar 3. Entity Relationship Diagram (ERD)

Pada gambar 3 merupakan relasi yang terdapat pada sistem KMS. Seperti yang sudah dijelaskan pada gambar 2, data user diambil dari sistem lain sehingga pada KMS tidak 
terdapat proses untuk mengelola user dan hanya digunakan untuk pencarian pengetahuan / informasi.

\section{Usecase Diagram}

Pada gambar 4 akan ditunjukkan usecase diagram yang telah dibuat sebagai analisis kebutuhan sistem.

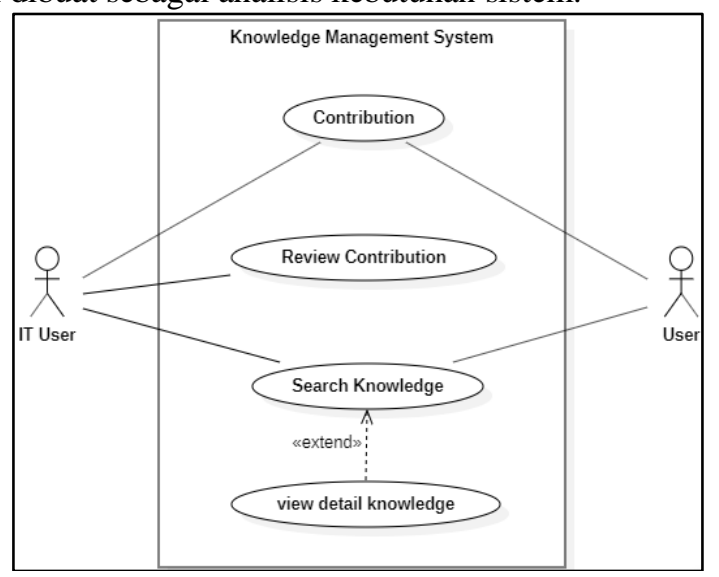

Gambar 4. Usecase diagram

Gambar 4 merupakan rancangan usecase diagram untuk $K M S$. Untuk level User biasa, dapat melakukan contribution, search knowledge, dan view detail knowledge. Untuk level User IT, dapat melakukan contribution, review contribution, search knowledge, dan view detail knowledge.

Penjelasan singkat mengenai usecase diagram:

- Contribution digunakan oleh semua pengguna yang akan membagikan informasi atau pengetahuannya.

- Review Contribution hanya dapa digunakan oleh IT User sebagai approval knowledge yang telah dibagikan oleh semua user sebagai filter agar KMS berisikan informasi yang valid dan dapat berguna untuk semua orang.

- Search Knowledge digunakan oleh semua user untuk mencari knowledge yang dibutuhkan.

- View Detail Knowledge digunakan untuk melihat detail informasi dari setiap knowledge.

\section{Sequence Diagram}

Pada bagian ini akan dibahas mengenail sebagian sequence diagram berdasarkan usecase diagram yang telah dibuat.

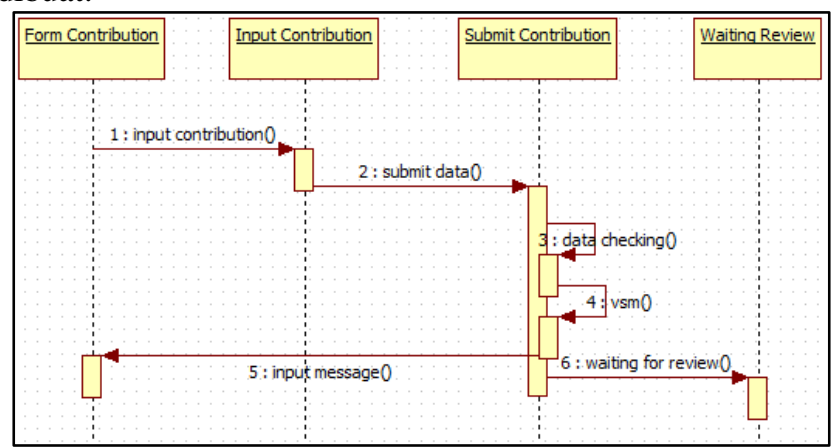

Gambar 5. Sequence diagram proses "Contribution"
Pada gambar 5 merupakan rancangan sequence diagram untuk proses "Contribution". Proses berawal dari form contribution, setelah user memasukkan contribution, sistem akan melakukan pengecekan input apakah sudah sesuai atau belum. Jika input sudah sesuai, maka sistem akan menjalankan proses VSM dan user akan menunggu review yang akan dilakukan oleh IT. Jika input salah, maka akan muncul pesan error.

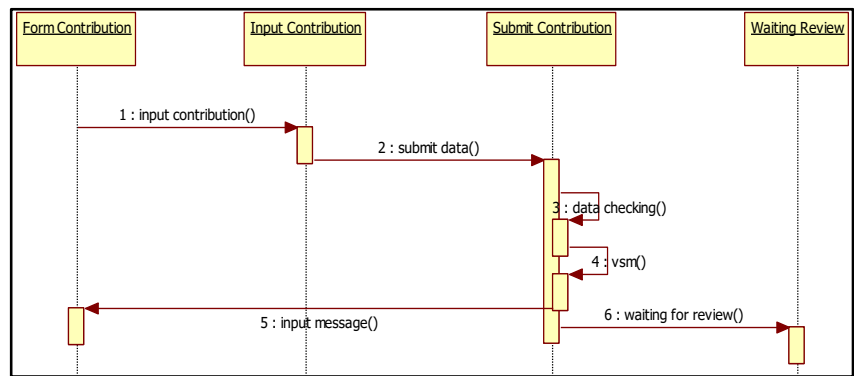

Gambar 6. Sequence diagram proses "Search Knowledge”

Gambar 6 merupakan rancangan sequence diagram untuk proses "Search Knowledge". Proses berawal dari halaman awal menu, user IT atau user biasa melakukan pencarian yang diinginkan. Sistem akan melakukan proses case folding, tokenizing, filtering, dan TF-IDF. Setelah semua proses sudah dilakukan, sistem akan menampilkan hasil yang dicari user.

\section{E. Activity Diagram}

Pada bagian ini akan dibahas mengenai sebagian activity diagram berdasarkan sequence diagram yang telah dibuat.

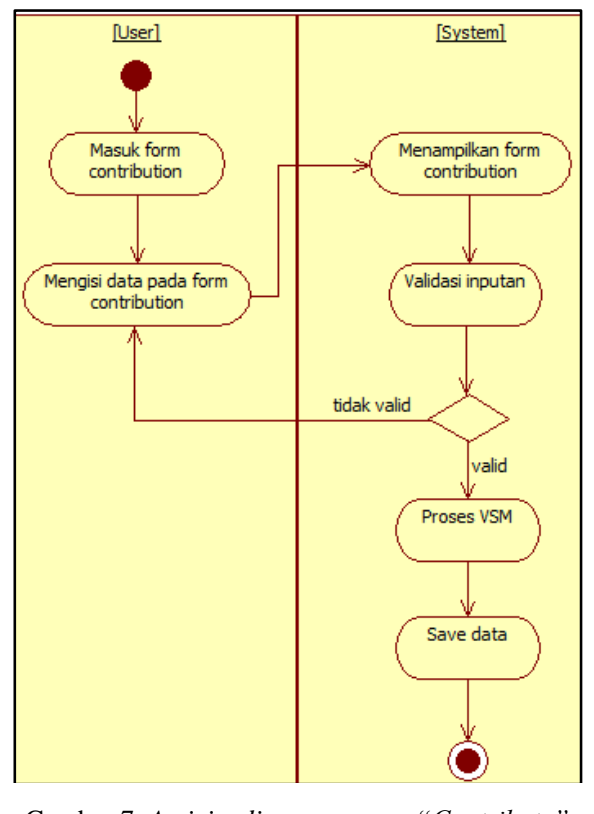

Gambar 7. Activity diagram proses "Contribute"

Gambar 7 merupakan rancangan activity diagram untuk proses contribution. Proses berawal dari masuk kedalam form contribution, lalu sistem akan menampilkan form 
contribution. Setelah itu user akan mengisi data pada form contribution. Setelah user "Submit", sistem akan melakukan pengecekan input, jika tidak valid, makan akan kembali pada form contribution, jika valid input akan disimpan pada database.

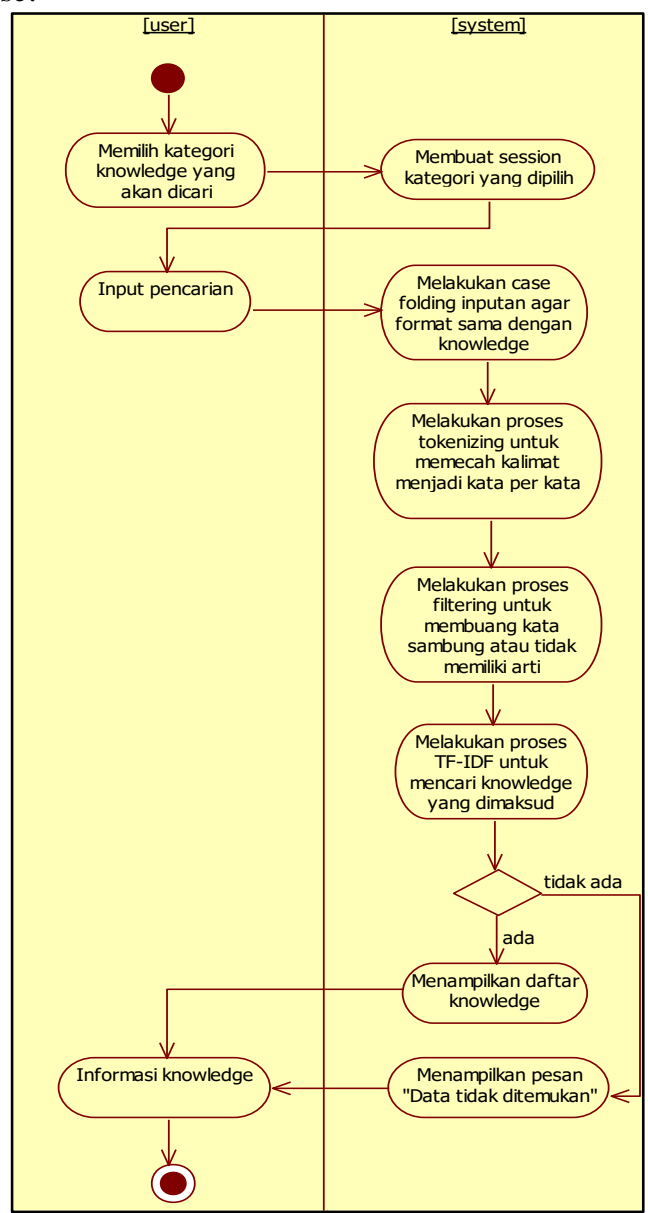

Gambar 8. Activity diagram proses "Search Knowledge"

Gambar 8 merupakan rancangan activity diagram untuk proses "Search Knowledge". User akan memilih knowledge apa yang akan dicari dan sistem akan membuat "session" untuk menyimpan pilihan user. Setelah user input pencarian, sistem akan melakukan case folding, tokenizing, filtering, dan $T F-I D F$ untuk mencari informasi yang mendekati kata kunci yang dicari. Jika informasi ditemukan, makan hasil akan ditampilkan berupa list, jika tidak ada hasil yang mendekati, maka akan menampilkan pesan "Data tidak ditemukan".

\section{F. Implementasi Sistem}

Setelah melewati beberapa proses analisis dan pembuatan sistem, serta dilakukan beberapa pengembangan untuk memenuhi kebutuhan user dan kebutuhan sistem, berikut dipaparkan hasil dari implementasi sistem.

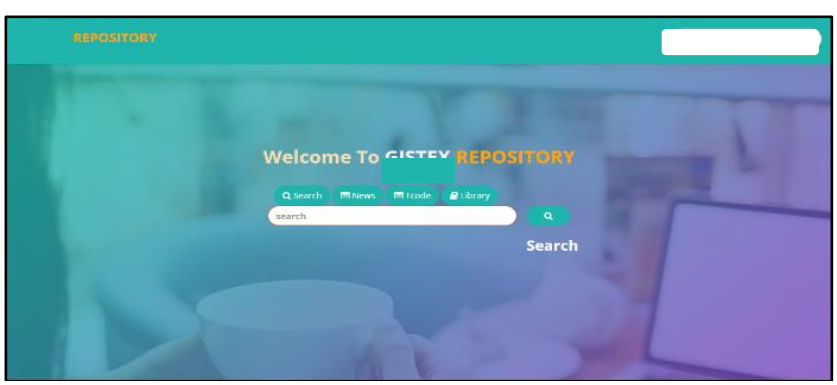

Gambar 9. Tampilan Halaman Awal KMS

Gambar 9 merupakan tampilan dari halaman awal sistem. Terdapat beberapa menu diantaranya menu search, news, TCode, dan library. Berdasarkan beberapa menu tersebut, yang menjadi fokus utama yaitu menu search, dan TCode. Menu search digunakan untuk pencarian pengetahuan, dan menu TCode digunakan untuk pencarian TCode SAP Standard yang diambil dari pihak luar. Hasil pencarian akan ditampilkan setelah user mengisikan pengetahuan yang akan dicari pada field search, lalu menekan tombol search.

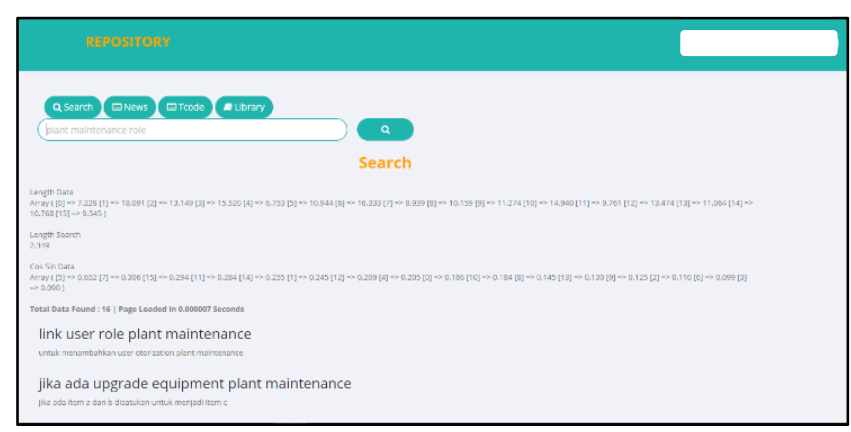

Gambar 10. Tampilan Hasil Pencarian KMS

Gambar 10 merupakan tampilan dari hasil pencarian pada menu search. Hasil yang dikeluarkan berupa daftar yang dapat menampilkan detail informasi jika menekan salah satu dari daftar yang ada. Pada bagian tengah gambar 10, dimunculkan sementara hasil perhitungan Cosine Similarity untuk membuktikan skor yang didapat dalam perhitungan. Pada array index merupakan nilai dari "idKnowledge" dan array value merupakan skor hasil perhitungan cosine similarity. Sebagai contoh untuk pencarian "plant maintenance role", hasil yang paling mendekati ada pada index 5 dengan nilai Cosine 0,652.

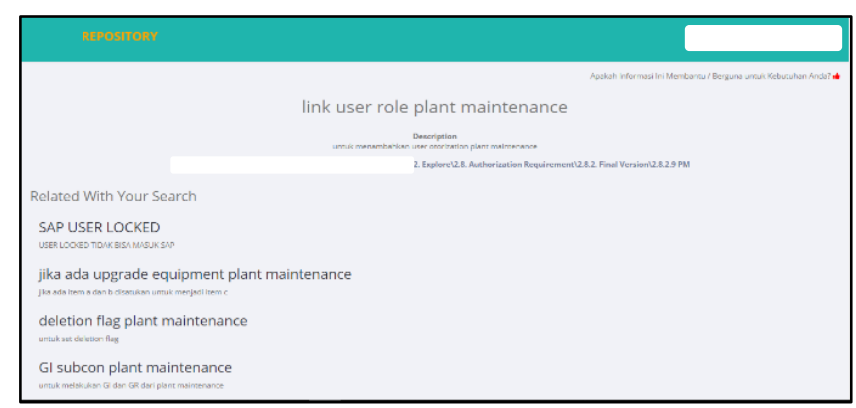

Gambar 11. Tampilan Detail Hasil Pencarian 
Gambar 11 merupakan tampilan dari detail hasil pencarian pada menu search. Detail hasil pencarian berisi informasi mengenai pesan error, judul pengetahuan, dsb; alasan terjadinya error, deskripsi pengetahuan, dsb; dan cara mengatasi error, isi atau penjabaran pengetahuan, dsb; daftar pencarian yang berhubungan; dan respon pencarian.

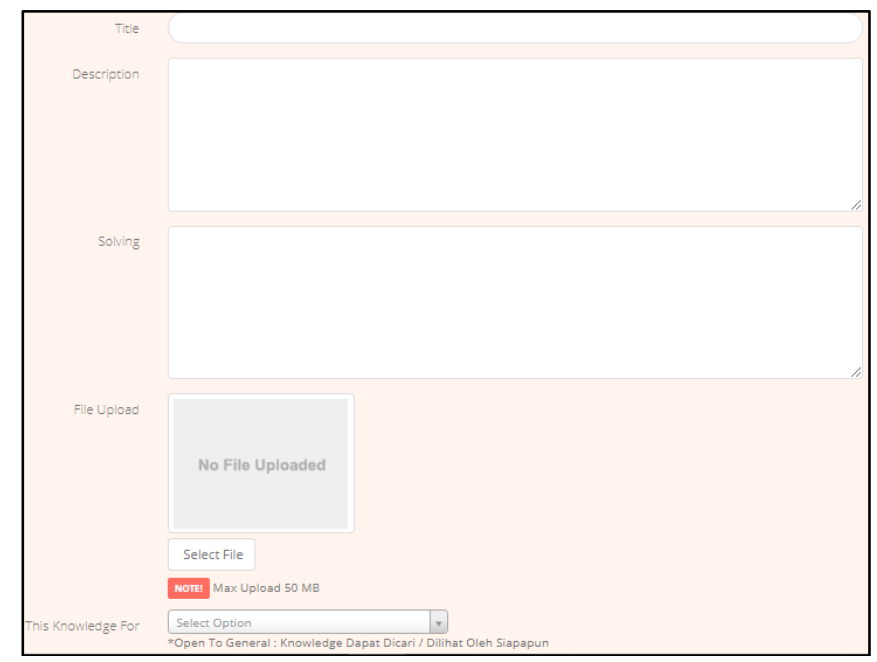

Gambar 12. Tampilan Contribution

Gambar 12 merupakan tampilan dari menu Contribution. Terdapat field untuk menambah pengetahuan berupa "Title" sebagai pesan error, judul pengetahuan, dsb; "Description" sebagai alasan terjadinya error, deskripsi pengetahuan, dsb; "Solving" sebagai cara mengatasi error, isi atau penjabaran pengetahuan, dsb; "Gambar" sebagai capture pesan error, cara mengatasi error, dsb; "This Knowledge For" sebagai pilihan untuk pencarian pengetahuan yang berupa "Open To General" jika pengetahuan dapat ditemukan oleh semua user, dan "Only To Department" jika pengetahuan hanya dapat ditemukan oleh user dengan departemen yang sama.

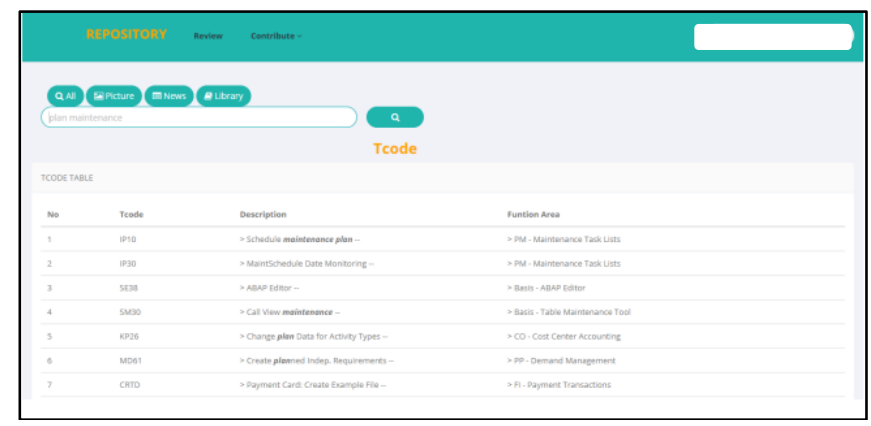

Gambar 13. Tampilan Hasil Pencarian TCode SAP

Gambar 13 merupakan tampilan dari hasil pencarian TCode Standard SAP berupa daftar TCode berdasarkan keyword yang dimasukan yang diambil dari pihak luar.

\section{ANALISIS DATA}

Dalam analisis data, akan dijabarkan mengenai analisis yang dilakukan setelah tahap implementasi Knowledge Management System (KMS) yang digunakan oleh kurang lebih 1000 user yang terdiri dari user biasa (Non IT) dan user admin (IT) yang telah digunakan sejak bulan Juni 2020.

1) Analisis Data Time Series Dengan ARIMA: tabel XI merupakan data tiket yang diambil sebelum implementasi sistem.

TABEL XI

TABEL DATA TIKET DARI SISTEM

\begin{tabular}{|c|c|c|c|}
\hline Bulan & Tahun & Jumlah & $\begin{array}{c}\text { Rata - rata per 20 } \\
\text { Hari Kerja }\end{array}$ \\
\hline 7 & 2019 & 153 & 8 \\
\hline 8 & 2019 & 265 & 13 \\
\hline 9 & 2019 & 279 & 14 \\
\hline 10 & 2019 & 337 & 17 \\
\hline 11 & 2019 & 441 & 22 \\
\hline 12 & 2019 & 352 & 18 \\
\hline 1 & 2020 & 322 & 16 \\
\hline 2 & 2020 & 490 & 25 \\
\hline
\end{tabular}

Tabel XI merupakan tabel jumlah tiket yang masuk dari Juli 2019 hingga Februari 2020 untuk semua kategori. Pada bulan Oktober 2019 hingga Desember 2019 adalah fase blackout untuk implementasi sistem baru (SAP), sedangkan fase Go Live dan penyesuaian $S A P$ terjadi pada bulan Januari 2020 hingga Februari 2020. Puncak tiket terbanyak terdapat pada bulan Februari 2020. Dengan data diatas, dapat diketahui bahwa dalam 1 hari, rata - rata tiket yang masuk berkisar antara 8 - 25 tiket dengan jumlah helpdesk hanya 1 orang, dan programmer yang membantu helpdesk ada 3 orang.

2) Pembuatan Model ARIMA: Pada proses ini, akan dilakukan pembentukan model ARIMA berdasarkan data yang ada. Pembentukan model dilakukan dengan data tiket yang masuk pada departemen IT.

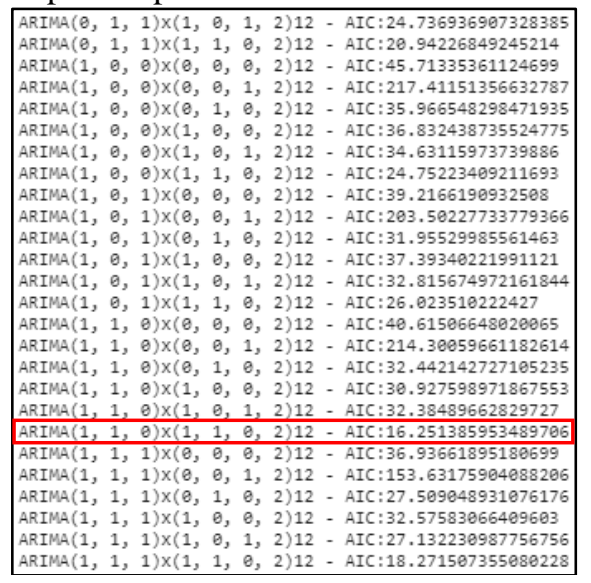

Gambar 14. Pembuatan Model ARIMA 
Gambar 14 merupakan sebagian dari pembuatan model ARIMA. Dapat dilihat bahwa model terbaik ada pada ARIMA $(1,1,0) \times(1,1,0,2)$ dengan nilai $A I C 16.25$.

3) Exploratory Data Training: Pada proses ini, dilakukan percobaan peramalan untuk bulan November 2019 hingga Februari 2020 menggunakan ARIMA dengan data tiket yang ada.

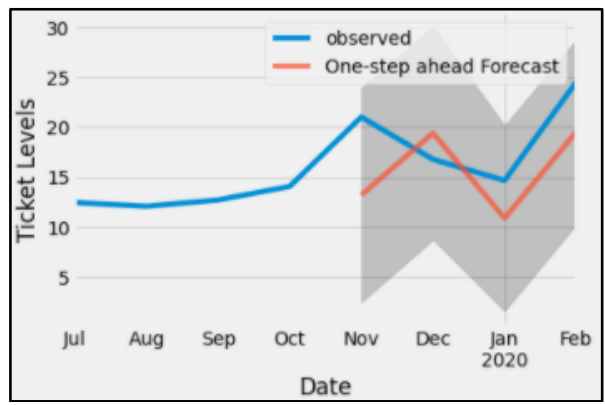

Gambar 15. Exploratory Data Training

Gambar 15 merupakan model peramalan data training menggunakan ARIMA untuk peramalan dari bulan November 2019 hingga Februari 2020. Model yang dibentuk hampir serupa dengan data aktual. Garis berwarna biru merupakan jumlah tiket yang ada, sedangkan garis berwarna jingga merupakan hasil peramalan yang dihasilkan dari jumlah tiket yang ada dengan nilai Mean Squared Error (MSE) yang didapat 26.82. Dengan percobaan tersebut dapat dilihat hasil dari peramalan tidak jauh berbeda dengan data aktual.

4) ARIMA Prediction Analytic: Setelah dilakukan percobaan peramalan data tiket, pada proses ini akan dibentuk peramalan data tiket yang akan terjadi pada bulan Maret 2020 hingga Februari 2021.

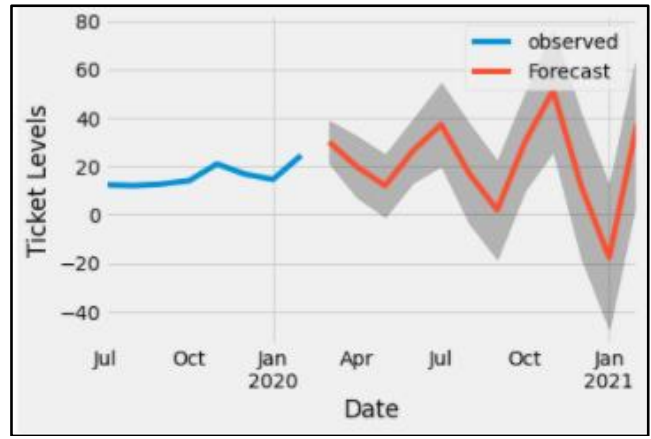

Gambar 16. ARIMA Prediction Analytic

Gambar 16 merupakan time series analytic menggunakan ARIMA. Dari data yang telah dikumpulkan sebelumnya, dilakukan peramalan terhadap trend tiket untuk 12 bulan kedepan dimulai dari bulan Maret 2020. Dapat dilihat trend terhadap tiket cenderung meningkat. Dengan hasil Perhitungan pada tabel 11, untuk rata - rata tiket per harinya diantara $8-25$ tiket, dan hasil dari peramalan pada gambar
8 untuk 12 bulan kedepan, maka dapat diasumsikan untuk trend tiket 12 bulan kedepan bisa 2 atau 3 kali lipat dari jumlah tiket sebelumnya dengan nilai Mean Squared Error (MSE) adalah 40.72 .

5) Ticket Data Model: Pada proses ini, dibuat model bedasarkan data tiket yang ada, yang akan dibagi berdasarkan kategori tiket berupa bug fix, complain, project, dan request.

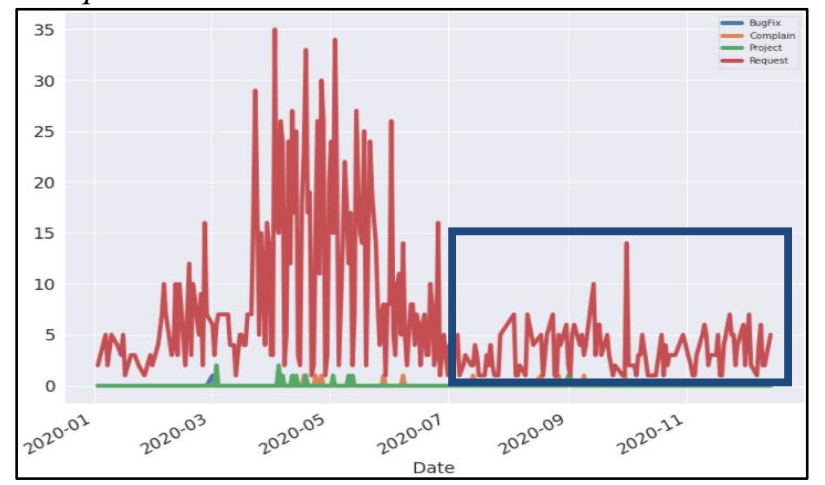

Gambar 17. Tiket data model

Dari analisis sebelumnya mengenai peramalan tiket yang akan terjadi 12 bulan kemudian, dan data tiket yang diambil khususnya untuk kategori $S A P$, dapat dilihat pada gambar 17 bahwa jumlah terbanyak ada pada tiket dengan jenis Request berada pada bulan April 2020 hingga Juni 2020 kurang lebih sebanyak 25 hingga 35. Dengan melihat trend yang akan terjadi dan aktual tiket yang masuk, maka dibuatlah sistem $K M S$. Dari data tersebut sangat terlihat perbedaan antara sebelum penerapan KMS dan sesudah $K M S$ (ditandai dengan kotak biru) dimana beban helpdesk terjadi penurunan. Berdasarkan data yang didapat sebelum dan setelah implementasi $K M S$, dapat dilihat bahwa rata rata tiket yang masuk berjumlah 14 hingga 25 per hari, dan setelah implementasi $K M S$ selama 6 bulan memiliki rata rata 5 per hari, atau dapat dikatakan bahwa beban helpdesk

6) Autocorrelation Request Ticket: Pada proses ini, akan dibuat model autocorrelation untuk melihat apakah terdapat varian atau tidak.

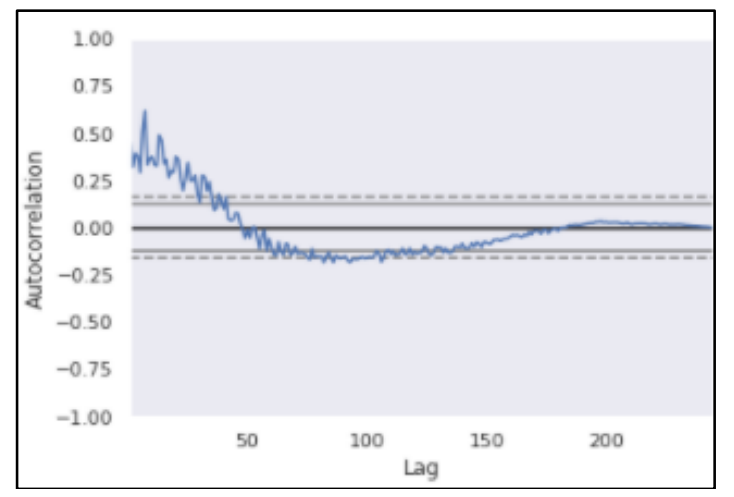

Gambar 18. Autocorrelation Request Tiket 
Gambar 18 merupakan model autocorrelation untuk tiket berdasarkan perhitungan korelasi antara jenis tiket yang masuk dengan Category SAP khususnya jenis request. Dapat dilihat, trend untuk setiap lag, cenderung sudah sesuai sehingga tidak terdapat data tidak stasioner dan difference pada model

\section{PENGUJIAN}

Dalam pengujian, dilakukan survei serta analisis data terkait untuk mengetahui apakah penelitian yang telah dilakukan sesuai dengan tujuan dan hipotesis yang ada.

1) Survei: Sebagai evaluasi mengenai solusi yang ditawarkan, dan kegunaan $K M S$ yang dapat membantu pekerjaan helpdesk, dilakukan survei kepuasan untuk KMS menggunakan platform Google Form yang dikirimkan kepada 61 responden dari berbagai departemen.

Berikut merupakan keterangan dalam pengisian survei:

- $\quad$ STB (Bernilai 1) = Sangat Tidak Baik

- TB (Bernilai 2) = Tidak Baik

- $\mathrm{C} \quad$ (Bernilai 3) $=$ Cukup $/>3$ Menit

- B (Bernilai 4) = Baik / $1-3$ Menit

- SB (Bernilai 5) = Sangat Baik $/<1$ Menit

TABEL XII

SURVEI UNTUK SEMUA USER

\begin{tabular}{|c|l|c|c|c|c|c|}
\hline No & \multicolumn{1}{|c|}{ Pertanyaan } & STB & TB & C & B & SB \\
\hline 1 & $\begin{array}{l}\text { Dari Pelayanan yang } \\
\text { Telah Anda Pakai, } \\
\text { Bagaimana Pelayanan } \\
\text { Kami? }\end{array}$ & & & & & \\
\hline 2 & $\begin{array}{l}\text { Bagaimana Kecepatan } \\
\text { Respon menggunakan } \\
\text { KMS? }\end{array}$ & & & & \\
\hline 3 & $\begin{array}{l}\text { Kecepatan } \\
\text { Penyelesaian Solusi / } \\
\text { Request (Problem } \\
\text { Solving)? }\end{array}$ & & & & & \\
\hline 4 & $\begin{array}{l}\text { Solusi yang Kami } \\
\text { Tawarkan dapat } \\
\text { Membantu Pekerjaan } \\
\text { Anda? }\end{array}$ & & & & & \\
\hline
\end{tabular}

Pada tabel XII, terdapat 4 pertanyaan yang akan diajukan dalam survei untuk semua user.

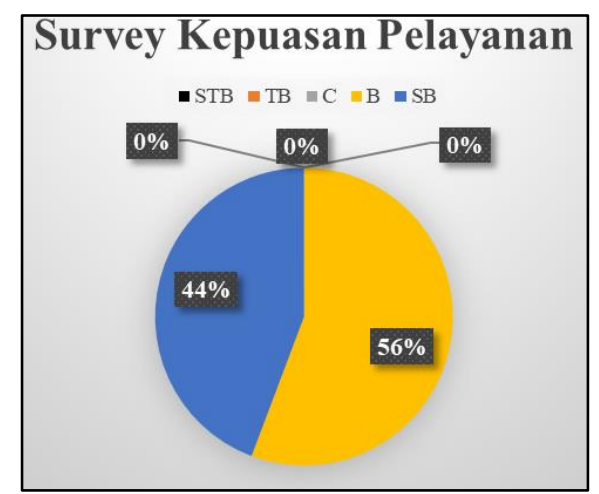

Gambar 19. Hasil Survei Terhadap Kepuasan Pelayanan (Semua User)
Pada gambar 19, dapat dilihat dari total 61 responden untuk pengguna $K M S$ dengan role user, dan 6 pengguna $K M S$ dengan role IT user, berikut hasil survei terhadap KMS yang telah digunakan. Pada gambar 19, dalam kepuasan pelayanan yang ditawarkan melalui $K M S$, didapatkan $56 \%$ responden memilih "Baik", dan 44\% responden memilih "Sangat Baik".

TABEL XIII

SURVEI UNTUK IT USER

\begin{tabular}{|c|l|c|c|c|c|c|}
\hline No & \multicolumn{1}{|c|}{ Pertanyaan } & STB & TB & C & B & SB \\
\hline 1 & Dari Pelayanan yang & & & & & \\
& Telah Anda Pakai, \\
& Beban Helpdesk \\
Berkurang $\pm 40 \% ?$ & & & & & \\
\hline
\end{tabular}

Pada tabel XIII, terdapat 1 pertanyaan yang akan diajukan pada survei untuk IT user.

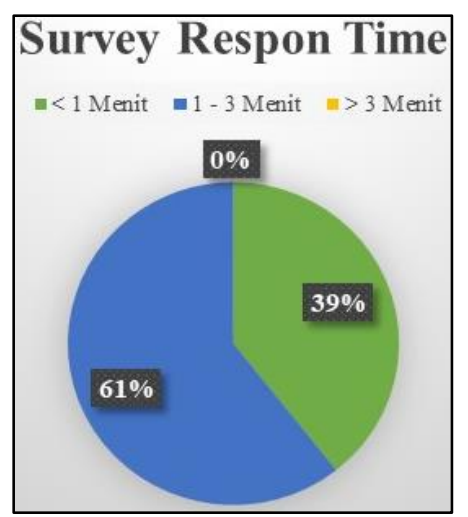

Gambar 20. Hasil Survei Terhadap Response Time (Semua User)

Pada gambar 20 ditampilkan hasil response time dalam pencarian data melalui $K M S$, dalam rentang waktu kurang dari 3 menit sebanyak $100 \%$ dimana $61 \%$ merupakan rentang waktu 1 - 3 menit, dan 39\% rentang waktu kurang dari 1 menit.

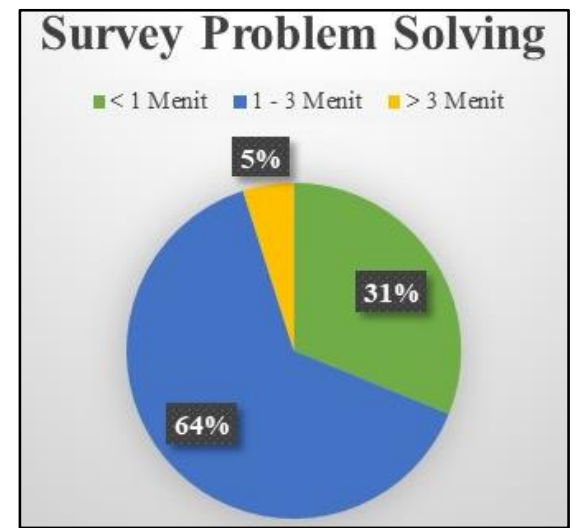

Gambar 21. Hasil Survei Terhadap Problem Solving (Semua User)

Pada gambar 21, ditampilkan hasil survei dalam pencarian data melalui $K M S$, untuk membantu user dalam hal problem solving, untuk rentang waktu $1-3$ menit 
sebanyak 64\%, kurang dari 1 menit sebanyak 31\%, dan lebih dari 3 menit sebanyak $5 \%$ yang dikarenakan data pada $K M S$ ini masih tidak terlalu banyak.

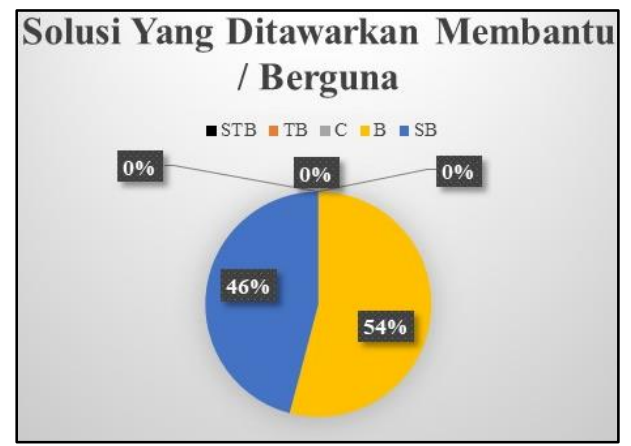

Gambar 22. Hasil Survei Terhadap Solusi Dapat Berguna / Membantu (Semua User)

Pada gambar 22, ditampilkan hasil survei terhadap solusi yang ditawarkan melalui $K M S$, 54\% responden menyatakan bahwa solusi dapat berguna atau membantu pekerjaan, dan $46 \%$ menyatakan solusi sangat berguna atau membantu pekerjaan.

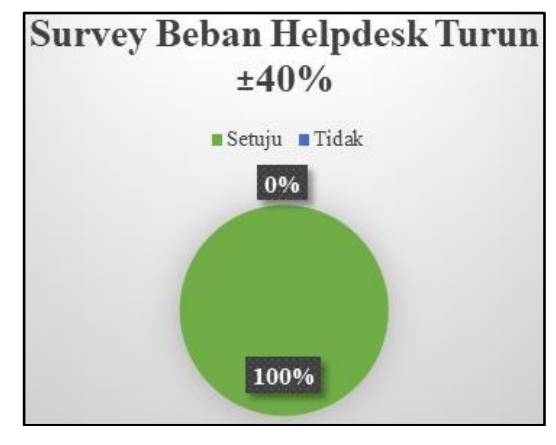

Gambar 23. Survei Beban Helpdesk (IT User)

Pada gambar 23, ditampilkan hasil survei dalam membantu menurunkan beban helpdesk untuk user IT, dari 6 responden terdapat $100 \%$ yang menyatakan bahwa beban helpdesk turun sebanyak $40 \%$.

Rangkuman survei yang telah didapatkan melalui 61 responden, ditunjukkan melalui tabel XIV. Nilai rata-rata yang diperoleh pada tabel XIV, yaitu 4.52 yang menyatakan antara Baik dan Sangat Baik.

TABEL XIV

RANGKUMAN SURVEI UNTUK IT USER

\begin{tabular}{|c|l|c|}
\hline No & \multicolumn{1}{|c|}{ Pertanyaan } & Rata - rata \\
\hline 1 & $\begin{array}{l}\text { Dari Pelayanan yang Telah Anda } \\
\text { Pakai, Bagaimana Pelayanan Kami? }\end{array}$ & 4.4 \\
\hline 2 & $\begin{array}{l}\text { Bagaimana Kecepatan Respon } \\
\text { menggunakan KMS? }\end{array}$ & 4.4 \\
\hline 3 & $\begin{array}{l}\text { Kecepatan Penyelesaian Solusi / } \\
\text { Request (Problem Solving)? }\end{array}$ & 4.3 \\
\hline 4 & $\begin{array}{l}\text { Solusi yang Kami Tawarkan dapat } \\
\text { Membantu Pekerjaan Anda? }\end{array}$ & 4.5 \\
\hline 5 & Beban helpdesk berkurang 40\%? & 5 \\
\hline \multicolumn{2}{|c|}{ Rata - Rata Total } \\
\hline
\end{tabular}

2) Analisis data setelah implementasi: Setelah implementasi sistem, dilakukan analisis data untuk mengetahui ketegori apa yang paling banyak digunakan, kata kunci apa yang paling banyak dicari, serta berapa banyak pengguna aktif $K M S$.

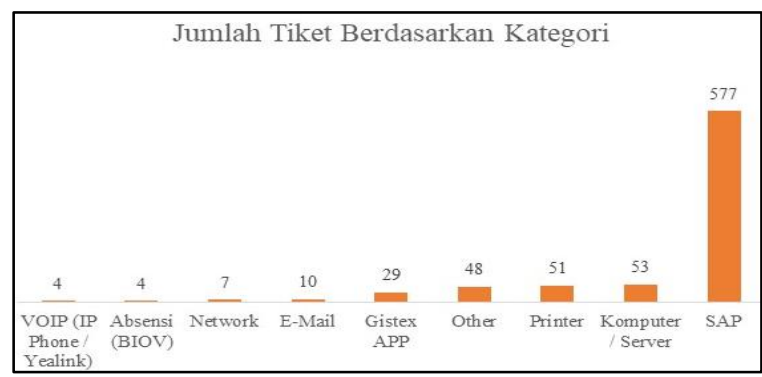

Gambar 24. Jumlah Tiket Berdasarkan Kategori

Pada gambar 24 ditunjukkan data tiket yang dikelompokkan berdasarkan kategori tiket yang diambil dari bulan Juli 2020 hingga bulan Desember 2020. Dapat dilihat bahwa kategori tiket terbanyak adalah $S A P$ dengan jumlah 577 tiket.

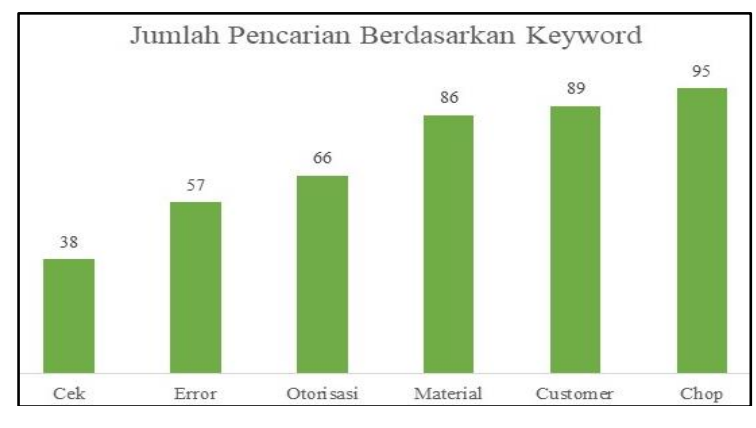

Gambar 25. Jumlah Pencarian Berdasarkan Keyword

Pada gambar 25 ditunjukkan data berdasarkan jumlah keyword yang dianggap popular untuk kategori tiket $S A P$. Dapat dilihat bahwa keyword "Chop" merupakan yang terbanyak dengan total 95 kali muncul, dan "Cek" merupakan yang terendah dengan jumlah 38. Dalam pengelompokan keyword untuk pemecahan masalah, keyword "Cek" dan "Error" bertotal 95 kali muncul.

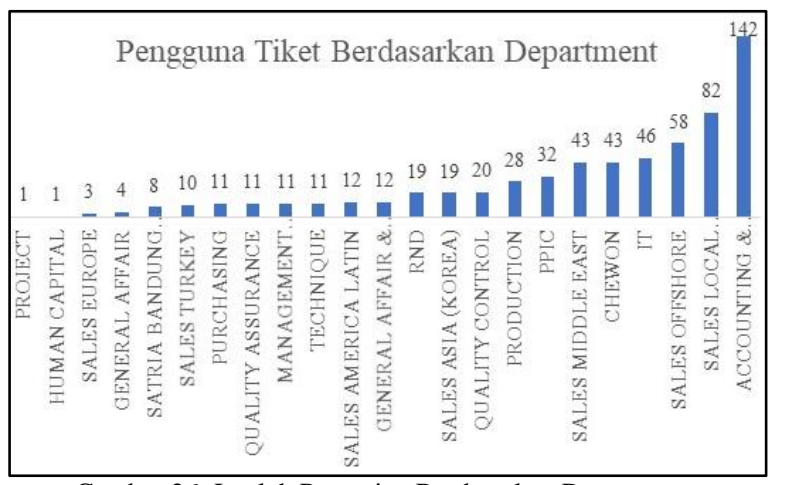

Gambar 26. Jumlah Pencarian Berdasarkan Departemen 
Pada gambar 26 ditunjukkan data berdasarkan jumlah pengguna tiket yang dikelompokan berdasarkan departemen. Dapat dilihat bahwa departemen terbanyak adalah "Accounting dan Finance", dan departemen terendah adalah "Project".

\section{SIMPULAN}

Dalam penelitian ini, telah dibuat sistem berupa $K M S$ yang diharapkan dapat membantu dalam pencarian pengetahuan / problem solving untuk user. Dengan menggunakan metode information retrieval mulai dari tokenizing, filtering, VSM, TF-IDF, dan juga Cosine Similarity, KMS dapat digunakan untuk membantu user dalam penentuan kandidat solusi berdasarkan pencarian pengetahuan, dan problem solving, serta membantu dalam menurunkan beban helpdesk sebanyak 4 hingga $5 \%$.

Dalam pencarian pengetahuan / problem solving, rata rata respon yang didapat kurang dari atau sama dengan 3 menit, dan dalam mendapatkan pengetahuan / problem solving, rata - rata user dapat menemukannya kurang dari atau sama dengan 3 menit dengan kategori terbanyak adalah "SAP", dan pengguna terbanyak adalah departemen "Finance dan Accounting".

\section{DAFTAR PUSTAKA}

[1] W. Dai, "Improvement and Implementation of Feature Weighting Algorithm TF-IDF in Text Classification," Advances in Intelligent Systems Research, vol. 147, pp. 583-587, 2018.

[2] (2016) Education Zone website. [Online]. Tersesdia: https://www.tabraniza.com/2016/11/sekilas-tentang-desainpenelitian.html

[3] Wiyanto, W. Priatna and J. S. Hidayat, "Implementasi Term Frequency -Inverse Document Frequency (Tf-Idf) Dan Vector Space Model (Vsm) Untuk Pencarian Berita Bahasa Indonesia," Pelita Teknologi: Jurnal Ilmiah Informatika, Arsitektur dan Lingkungan, vol. 14 , no. 2 , pp. 119-133, 2019

[4] (2018) School of Computer Science Binus website. [Online]. Tersedia: https://socs.binus.ac.id/2018/11/29/vector-space-modeldalam-pengolahan-teks/

[5] H. Smuts, A. v. d. Merwe, M. Loock and P. Kotzé, "A Framework and Methodology for Knowledge Management System
Implementation," ACM International Conference Proceeding Series, 2009, p. 70-79.

[6] L. Sitorus, Algoritma Dan Pemrograman, 1st ed., Yogyakarta, Indonesia: Andi 2015, pp. 14-16

[7] W. Sahayu. (2013) http://staff.uny.ac.id/. [Online]. Tersedia: http://staff.uny.ac.id/sites/default/files/pendidikan/Dra.\%20Wening \%20Sahayu,\%20M.Pd./Makalah\%20Hipotesis.pdf. [Accessed 31 March 2020]

[8] E. Sadewo. (2013) ResearchGate. [Online]. Tersedia https://www.researchgate.net/publication/311558057_Perbandingan _Beberapa_Metode_Time_Series_Pada_Peramalan_Jumlah_Kunjun gan_Wisatawan_Mancanegara_Studi_Kasus_Di_Kabupaten_Karim un_Provinsi_Kepulauan_Riau

[9] O. Karnalim, "Extended Vector Space Model with Semantic Relatedness on Java Archive Search Engine," Jurnal Teknik Informatika dan Sistem Informasi (JuTiSi), vol. I, no. 2, p. 111, 2015.

[10] A. Ryansyah and S. Andayani, "Implementasi Algoritma TF-IDF Pada Pengukuran Kesamaan Dokumen,” Jurnal Sistem \& Teknologi Informasi Komunikasi, vol. 1, no. 1, pp. 1-10.

[11] S. Qaiser and R. Ali, "Text Mining: Use of TF-IDF to Examine the Relevance of Words to Documents," International Journal of Computer Applications, vol. 181, no. 1, pp. 25-29, 2018.

[12] M. Nurjannah, Hamdani and I. F. Astuti, "Penerapan Algoritma Term Frequency-Inverse Document Frequency (Tf-Idf) Untuk Text Mining," Jurnal Informatika Mulawarman, vol. 8, no. 3, pp. 110$113,2013$.

[13] A. A. Maarif. (2015) eprints homepage on UDiNus Repository. [Online]. Tersedia: http://eprints.dinus.ac.id/15283/

[14] Kusrini, Strategi Perancangan dan Pengelolaan Basis Data, Yogyakarta, Indonesia: Andi 2007, pp. 10, 49-50.

[15] S. V. Kant and V. K. Singh, "Vector Space Model: An Information Retrieval," International Journal of Advanced Engineering Research and Studies, vol. IV, pp. 141-143, 2015.

[16] A. Josi, L. A. Abdillah and Suryayusra, "Penerapan teknik web scraping pada mesin pencari artikel ilmiah," Jurnal Sistem Informasi (SISFO), vol. 5, no. 2, pp. 159-164, 2014.

[17] A. Irawan and N. K. Setiyorini, "Rancang Bangun Aplikasi helpdesk Dengan Menggunakan Pendekatan Knowledge Management System Pada Seksi Teknisi pt. Indah kiat pulp \& paper tbk," Jurnal ProTekInfo, vol. 4, pp. 6-11, 2017.

[18] B. Herwijayanti, D. E. Ratnawati and L. Muflikhah, "Klasifikasi Berita Online dengan menggunakan Pembobotan TF-IDF dan Cosine Similarity," Jurnal Pengembangan Teknologi Informasi dan Ilmu Komputer, vol. 2, no. 1, pp. 306-3012, 2018.

[19] M. O. Igbinovia and I. J. Ikenwe, "Knowledge management: processes and systems," Information Impact: Journal of Information and Knowledge Management, vol. 8, pp. 26, Feb. 2018. 